LA- -9217-MS

Issued: Januarỳ 1982

DE82 008751

\title{
An Analysis of the \\ Alleged Kyshtym Disaster
}

Diane M. Soran

Danny B. Stillman

NOTICE

PORTIONS OF TUIS REPORT ARE ILLEGIBLE. It

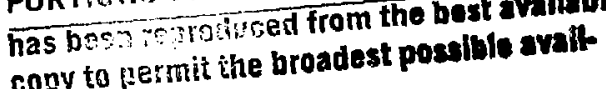
ability.

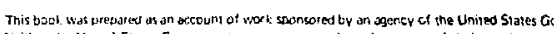

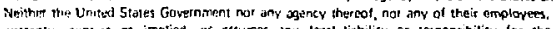

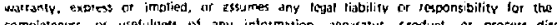

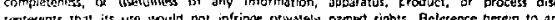

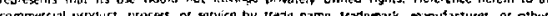

camme cial in

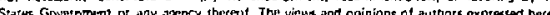

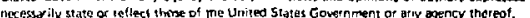

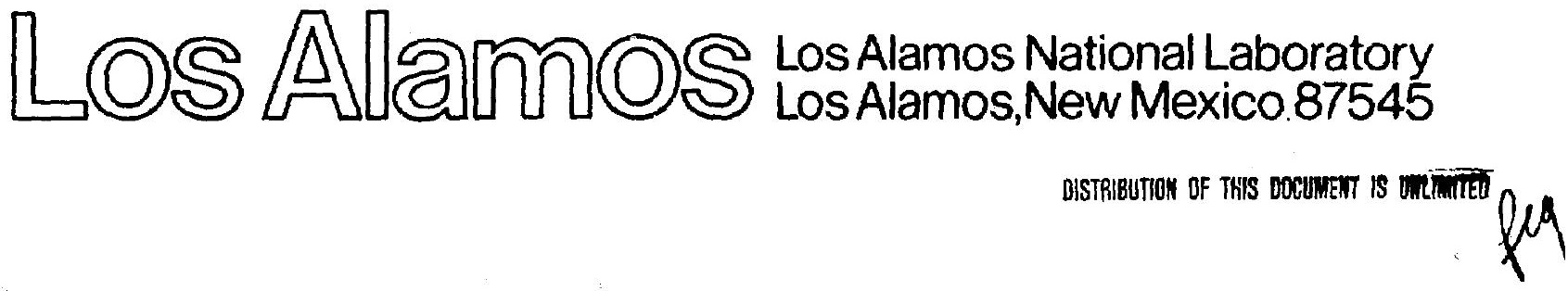




\title{
AN ANALYSIS OF THE ALLEGED KYSHTYM DISASTER
}

\author{
by
}

Diane M. Soran and Danny B. Stillman

\begin{abstract}
The alleged Kyshtym disaster has been an intriguing intelligence puzzle for almost 25 years. zhores Medvedev, a Soviet dissident, has written numerous journal articles as well as two books on the subject. He has argued that a vast contaminated area exists east of the city of Kyshtym in the southern Ural Mountains. Further, he has alleged that a nuclear waste disposal accident in 1957-58 caused the contamination.

The authors of this report are in partial disagreement with Medvedev's first allegation and in complete disagreement with his second. A contaminated area does exist east of Kyshtym, but Soviet carelessness coupled with general disregard for the citizenry and the environment are the prime causative factors, not a nuclear waste accident.
\end{abstract}

\section{INTRODUCTION}

The so-called Kysitym Disaster has been an intriguing puzzle for more than 20 years. The city of Kyshtym $\left(55^{\circ} 42 \cdot \mathrm{N} 60^{\circ} 34^{\prime} \mathrm{E}\right)$ is located on the east side of the Ural Mountains on the railroad linking the industrial cities of Chelyabinsk and Sverdlovsk (Fig. 1). The area has a long history of munitions production dating back to the time of the tsars. It is in this region that the Soviets chose to build their first plutonium production facility in the late 1940s.

The Kyshtym Complex lies approximately $15 \mathrm{~km}$ east of the city of Kyshtym on the south shore of Lake Kyzyltash. The Soviets 


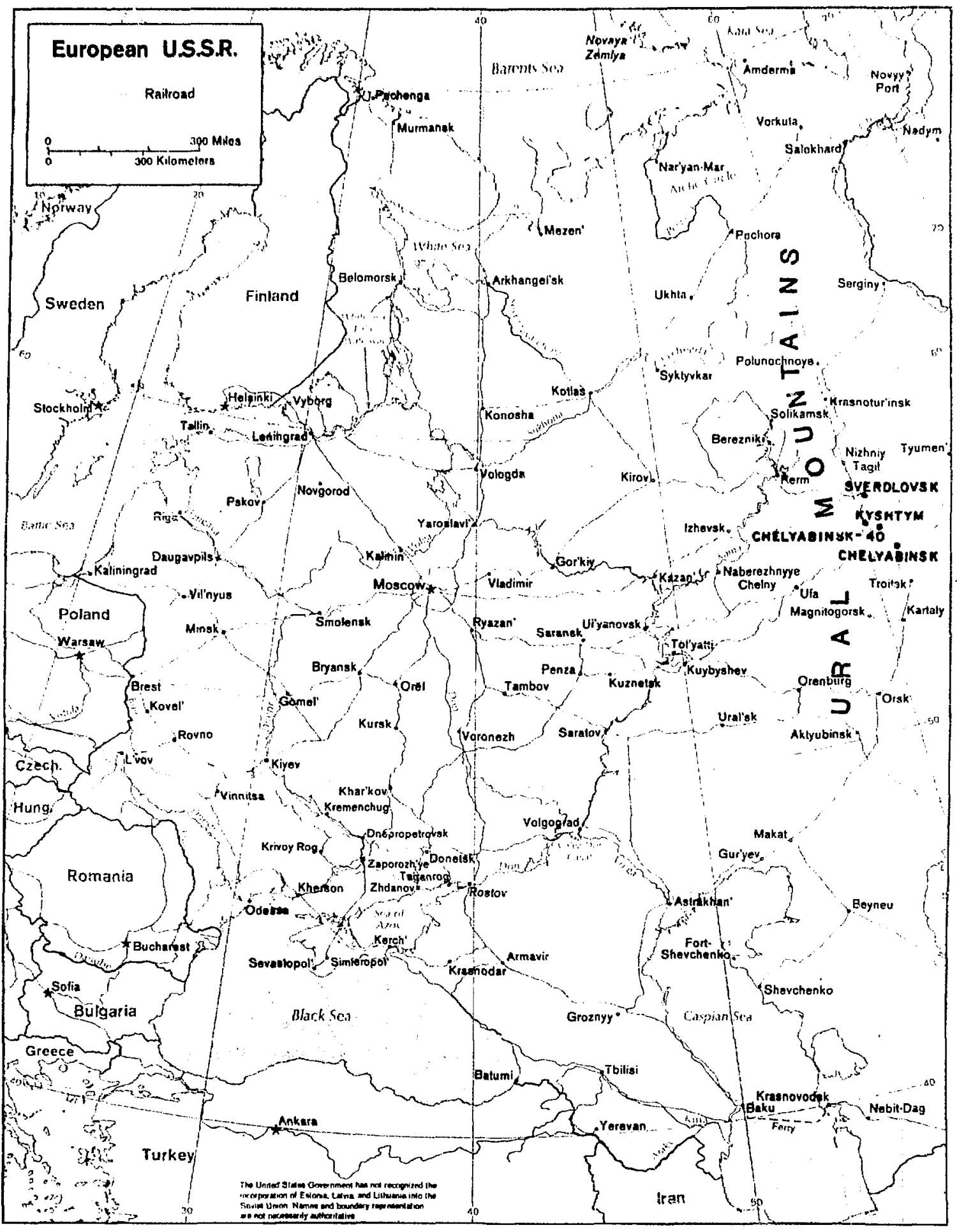

Fig. 1 .

Location map showing Kyshtym area. 
refer to it as chelyabinsk-40. This is a typical soviet identification scheme for closed institutes: the name of a nearby city and a numerical designator.

In April 1958, a Copenhagen newspaper reported a "catastrophic accident" involving soriet nuclear weapons tests and linked it to the Soviet unilateral suspension of nuclear weapons tests in March 1958. Accounts of a serious accident in a "Soviet Atomic Plant:" appeared in an Austrian newspaper in 1959. In 1962 the incident was mentioned in "Review of Nuclear Incidents" as an "unconfirmed report of a major reactor incident." And, in 1976 zhores Medvedev, an exiled Soviet geneticist, brought the "incident" to the attention of the scientific community by claiming that buried nuclear waste material near Kyshtym exploded, killing hundreds of people and contaminating "a large area, probably more than a thousand square miles in size."

Today, the Kyshtym Disaster is no longer merely an intriguing enigma. The allegations surrounding it bear heavily on the whole question of nuclear waste disposal in the US. Medvedev's assertions, therefore, must be examined impartially to determine what really happened at kyshtym.

This document has been prepared at the request of the Department of Energy and represents our current thinking.

\section{BACKGROUND}

In late 1976, Zhores Medvedev, an exiled Soviet geneticist living in England, began publishing articles in the New Scientist, presenting colloquia at Oak Ridge National Laboratory and Los Alamos National Laboratory, and writing books (Soviet Science and Nuclear Disaster in the Urals) on the occurrence of a nuclear disaster in the Ural Mountains of the Soviet Union circa 1957-58.

Medvedev conducted a review of open soviet radioecological literature to substantiate rumors of a disaster and to delineate the area in the Urals contaminated as a result of such a disaster. Working under the premise that soviet scientists would have utilized such a vast contaminated area for on-site research programs, he reviewed soviet journal articles and inferred research 
sites from the flora and fauna mentioned in those articles. He concluded that a vast area of radioactive contamination extending "probably more than a thousand square miles" exists in chelyabinsk province, east of the city of kyshtym. He further alleged that in the 1957-58 time frame, a volcano-like eruption of nuclear waste that had been buried in the vicinity of kyshtym was the cause of the contaminated zone. By his account, "the explosion poured radioactive dust and materials high up into the sky," and "strong winds blew the radioactive clouds hundreds of miles away. . . Tens of thousands of people were affected, hundreds dying, though the real figures have never been made public."

Medvedev's allegations of a vast contaminated area were corroborated by an account of Lev Tumerman, a Soviet scientist who in 1960 traveled along the Chelyabinsk-Sverdlovsk highway, which traverse:s the alleged contaminated area. Tumerman emigrated to Israel in 1972 and is affiliated with the Weizmarn Institute of Science, Rehovot, Israel. He stated in letters to the Jerusalem Post, and to The London Times that:
"About 100 kilometres from Sverdlovsk, a high- way sign warned drivers not to stop for the next 20 or $30 \mathrm{kilometres}$ and to $d r$ ive through at maximum speed. On both sides of the road, as far as one could see, the land was 'dead': no villages, no towns, only the chimneys of de- stroyed houses, no cultivated fields or pas- tures, no herds, no people...nothing."

In personal correspondence with the authors of this report, Tumerman further stated:
"What I saw personally, was a large area in the vicinity of Sveralovsk (no less than 100 to 150 sq. $\mathrm{km}$ and probably much more), in which any normal human activity was forbidden, people were evacuated and villages razed, evidently to prevent inhabitants from returning, there was no agriculture or live-stock raising, fishing and hunting were forbidden, ..."

Also, in his communication with the authors of this report, Tumerman carefully differentiated between what he saw, as quoted above, and what he was told:

"What I was told by many people in Sverdlovsk and Beloyarsk, was that the fallout was a consequence of a major nuciear explosion on a 
military nuclear plant near Kyshtym. They said that many (perhaps hundreds) of people were killed or injured. Berause a disaster of such magnitude couldn't reasonably be kept secret from the local population, I believe that this information was essentialiy true. But nobody had any information as to the nature of the explosion."

Medvedev's allegations received additional support from the publication, in 1979, of an Oak Ridge National Laboratory report entitled "Analysis of the 1957-58 Soviet Nuclear Accident." The Oak Ridge study followed Medvedev's approach to the problem and reviewed over 150 soviet open literature articles dealing with radioecology. Not surprisingly, the Oak Ridge authors arrived at Medvedev's conclusions that, in fact, a vast contaminated area did exist in the southern Urals. However, the report did not provide an objective analysis of the Kyshtym accident. That problem remains, as yet, unsolved. The answer, of course, can come only from the soviets.

Still, an attempt must be made, in light of the current nuclear waste disposal questions facing the US, to understand what occurred in the urals circa 1957-58. Further, since the existence of a vast contaminated area east of Kyshtym has been alleged by two independent studies and one eyewitness account, some attempt to understand its cause must be made.

\section{KYSHTYM COMPLEX - -HANFORD COMPLEX}

There can be no doubt that soviet physicists owe much to the Smyth report..-"Atomic Energy for Military Purposes"--by Henry D. Smyth. That document summarized all that it was felt safe to reveal at the time of its publication in August 1945. Some have even called it the soviet Bible. Its contents range from basic nuclear physics to a chapter entitled "The work on the Atomic Bomb." The Hanford complex is identified in the text as the lecation of us plutonium production facilities.

In an October 22, 1949, New York Times article, Lieut. Gen. Leslie R. Groves, wartime head of the Manhattan project, said that in 1942 he told Gen. George C. Marshall, then Army Chief of staff; that some other nation would develop the atom bomb within twenty 
years. "The Russians (sic) did it in a shorter time, because they got information from us." Perhaps soviet agents in this country were able to piece together scraps of information gathered in conversations with American physicists from facilities identified in the Smyth report.

It seems reasonable that parallels may be drawn between the US plutonium production complex at Hanford, Washington, and the Kyshtym Complex, Chelyabinsk province, because Hanford technology was identified as established, state-of-the-art technology by 1947 when the Soviets began construction at chelyabinsk-40. The analysis put forth in this report is based on that supposition, and supporting evidence will be indicated.

IV. KYSHTYM COMPLEX--FIRST SOVIET PLUTONIUM PRODUCTION FACILITY Academician Igor Vasil'evich Kurchatov has rightfully been called the father of atomic science in the Soviet Union. His Soviet biographer, I. N. Golovin,* states:

"No other scientist of ours contributed so much as Kurchatov to building the soviet atomic weapon and atomic electric power stations or to the development of atomic technology and the science of the atomic nucleus."

The construction of the first soviet uranium-graphite reactor, F-l, as well as the construction of the first industrial uranium reacto: for the production of plutonium were both directed by Kurchatov.

The location of the first Soviet plutonium production complex near the city of Kyshtym is suggested by independent sources utilizing I. V. Kurchatov as the connection.

First, Golovin states:

"In a scenic spot far from Moscow work was progressing on a city and its industrial equipment and chemical plants. In January, 1947. Kurchatov sent off his closest collaborators from Laboratory No. 2 to be on hand when

\#I. N. Golovin, I. V. Kurchatov, A Socialist-Realist Biography of the Soviet Nuclear Scientist, translated by $w . H$. Dougherty (The Selbstverlag Press, Bloomington, Ind.. 1968). 
the foundation was laid for the first uranium pile and to help with construction.

In the fall of 1947, with the coming of freezing weather, I. V. Kurchatov and B. L. Vannikov arrived at the building site. A large city had already sprung up there, populated by thousands of workmen, technicians, and engineers of various categories. The place where the pile was under construction was over ten kilometers from town, ..."

Thus, Kurchatov was responsible for the construction of the first Soviet plutonium production complex.

Second, other information states that academician I. V. Kurchatov resided at the plant (Kyshtym Industrial complex) at least until the early 1950s and apparently held the major scientific supervisory post. Kurchatov, then, provides the connection between the first soviet plutonium production complex and the Kyshtym complex.

Information gleaned from Kurchatov's biography can then be coordinated with data supplied from other sources, and parallels can be drawn from the Hanford experience to recreate the physical layout of the Kyshtym Complex 1946-57.

V. KYSHTYM PLUTONIUM PRODUCTION REACTORS

The first plutonium production reactor built at the Kyshtym Complex was known as unit 0 to the soviets. Golovin* identifies it as a graphite moderated, uranium-metal fueled reactor.

"When the stacking of the graphite began, stringent precautions were taken to prevent accidental contamination by boron.

The graphite was $\dot{i a} \dot{i d}, \dot{a}$ and then came the touchiest stage of the assembly--loading the pile with uranium.

The first pile had been loaded with all the uranium metal then available in the country."

Information from someone familiar with the Kyshtym complex has provided the following details on Unit 0 . 
"This reactor was called Unit 0 (zero, or Nulevoy ob'yekt). . . . it was the first major project constructed in the Kyshtym complex.

The reactor in Unit 0 was a graphite moderated reactor and almost certainly had vertical rather than horizontal fuel channels. . . the cooling system was open cycle, because a large quantity of radioactive water was disposed of in a nearby artificial lake.

There were no streams or rivers flowing through the Industrial zone, with the exception of a small river flowing out of the zone from the artificial lake into which effluences were fumped."

Additional information indicates that prior to August 1950, a large artificial lake was dug in the northeastern part of the Industrial zone of the Kyshtym Complex. Used cooling water from Unit 0 , a reactor that began operating before that date, was pumped into this artificial lake. By 1952, used cooling water from two more reactors, Units 301 and 701 , was also pumped into this artificial lake. And by 1953, the water in this artificial lake had become dangerously radioactive. A small stream called the River Tech' flowed out of the artificial lake in a northeaster ly direction.

Figure 2 is a copy of a US Army Map Service map printed in November 1955. The data used to compile it were soviet data from 1936-41. The Kyshtym complex does not appear on the south shore of Lake Kyzyltash because construction did not begin until 1947. However, we have indicated the location of the complex. The map does provide a view of the area as it must have looked in the early stages of development of Chelyabinsk-40.

One of the more obvious examples of the parallelism between the Kyshtym Complex and the Hanford complex is the reactor cooling cycle. The reactors at Hanford were cooled via an open cycle system. Water was pumped from the Columbia River, treated, circulated through the reactor core, held in storage tanks for 3.3 hours, and returned to the columbia. The level of radioactivity in the effluent was carefully monitored, and any contaminated cooling water could have been diverted into a mile-long trench and 


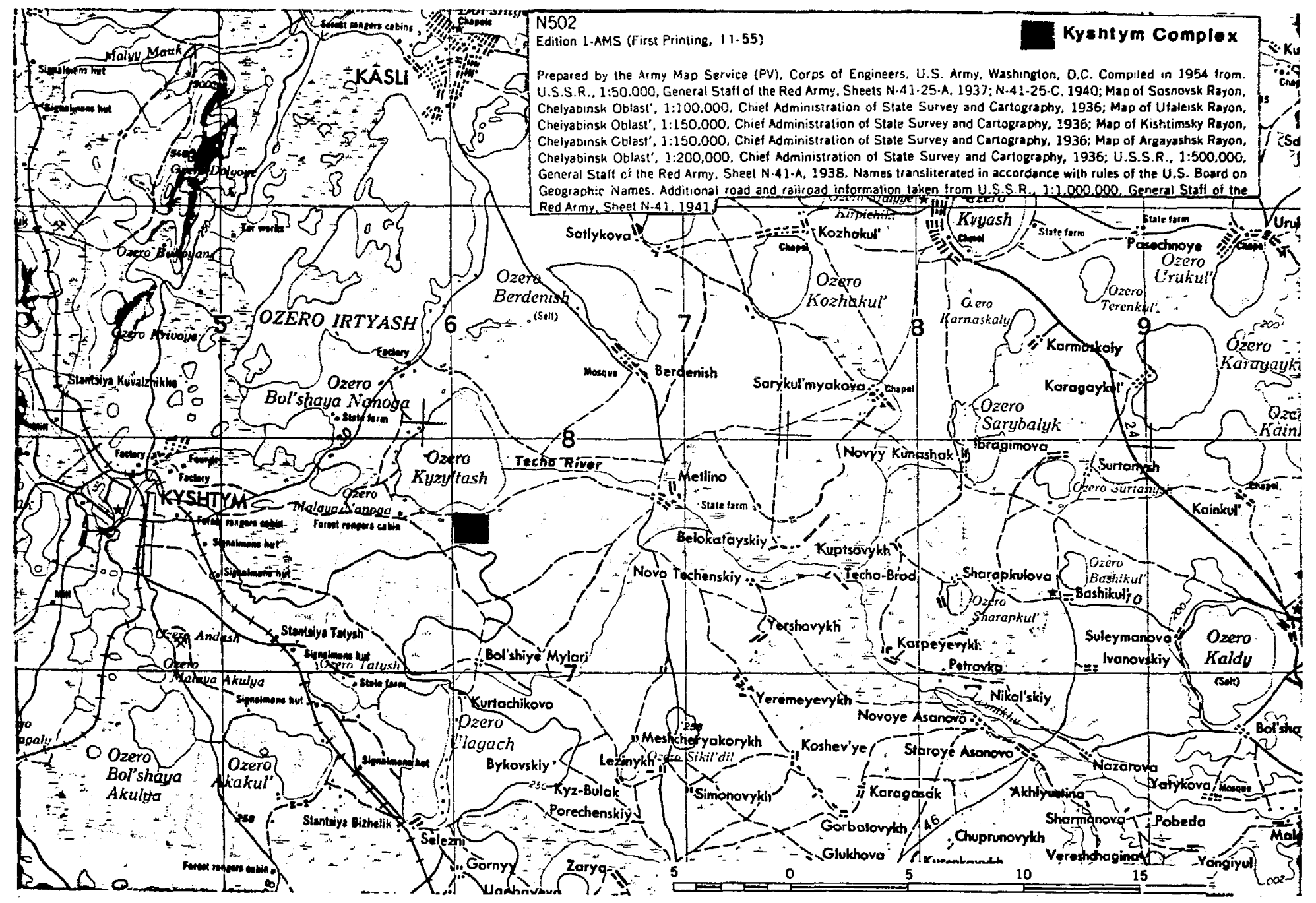

Fig. 2.

Kyshtym area (pre-complex). 
additional holding basin facilities if radiaactivity levels had ever necessitated such action.

The cooling cycle for the reactors at the Kyshtym Complex was probably very similar. We suggest that cooling water was pumped from Lake Kyzyltash, treated, circulated through the reactor core, held in the nearby "artificial lake," and emptied into the Techa River. Indeed, the effluent entering the Techa River has been identified as emanating from a radioactively contaminated lake (holding pond). Reactor fuel cladding in the 1940 s was an example of art commingled with science, and cladding failures could release fission products into the cooling water as it circulated through the reactor. Information even refers to the "leaky" reactors at Kyshtym. Frequent cladding failures could account for the "large quantity of radioactive water" in the "artificial lake" (holding pond). Further, whereas the average flow of the columbia River at the Hanford site is $121,000 \mathrm{cu} \mathrm{ft} / \mathrm{s}$, with an average monthly minimum of 40,000 in February and a maximum of 334,000 in June, the flow rate of the Techa River has been estimated from the drainage area and climatological data in the region to range annually from 95 to $130 \mathrm{cu} f t / s$. The flow rate of the Techa River is, therefore, orders of magnitude less than that of the Columbia. The radioactive water would therefore be in contact with the riverbank appreciably longer in the Techa River Valley, and the fission product contamination of the environs could take place readily.

Thus, the entrance of radioactively contaminated effluent into the Techa River, at least as early as 1953, establishes a chronic, waterborne source of radioactive contamination in the Techa River valley long before any suggested Kyshtym disaster date.

VI. CHEMICAL SEPARATION

Sequentially, the next operation at a plutonium production facility is the separation of plutonium from the irradiated reactor fuel elements. 
We can only speculate as to the specific process the soviets used. Kurchatov's biographer* implies the investigation of at least two different processes in 1947. At that time they experimented on plutonium accumulated from the experimental pile, F-l.

"In 1947 from two samples of uranium irradiated by the F-I [two soviet scientists] for the first time in the USSR extracted by two distinct methods two portions of plutonium-239, weighing 6 and 17 micrograms, and investigated its most important chemical properties. Applying the method that $y$ ielded the greater amount of plutonium, B. A. Nikitin and A. P. Ratner in the Radium Institute, under the supervision of Academician V. G. Khlopin, elaborated the technology on which the industrial extraction of plutonium from uranium was based. The plant buildings were by then already under construction."

Whatever process the Soviets litimately used had to involve fuel cladding removal and dissolution of the irradiated fuel elements (uranium slugs) in nitric acid. It is the off gas generated in the dissolution that is thought to be a contributory factor in the aerosol pollution in the Techa River Valley.

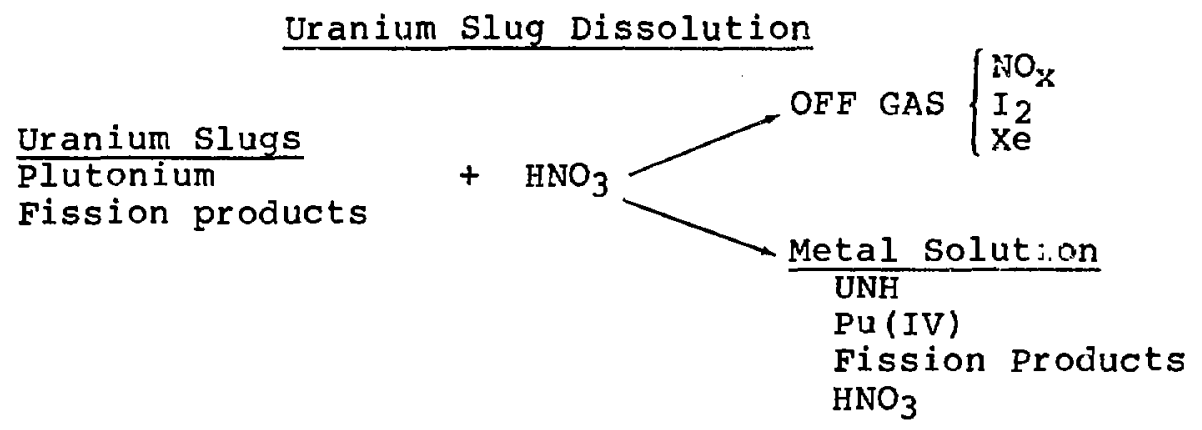

Available details on a Kyshtym unit described as an "enrichment plant" are very similar to US plutonium processing facilities. In fact, the similarities are so marked as to imply that us design information had been used. This is an excellent example of the dependence of Soviet technology at Kyshtym on Us technology at 
Hanford and lends credibility to the original supposition upon which this analysis is based.

The smokestack of the Kyshtym enrichment plant was reported to be $150 \mathrm{~m} \mathrm{high,} 12 \mathrm{~m}$ in diameter at the base, and $4 \mathrm{~m}$ in diameter at its top. Information indicates that once this plant was operational, smoke was exhausted from the stack 24 hours a day for months and then years in a row; no cessations or temporar" diminutions were observed. The smoke was yeliorish and, according to rumors, was a mixture of steam and acids, and possibly nitrogen. For a distance of $15-20 \mathrm{~km}$ from the stack, the grasses and trees yellowed and died.

Here is an example of two types of air pollution, chemical as well as potentially radioactive. In the kyshtym area the relative humidity is high throughout the year, ranging from 638 in May to as high as $82 \%$ in November. The nitrogen oxides in the off gas react with water and combine to produce nitric acid, therefore acid rain or acid-laden snow, which is responsible for the "dead" areas--a simple case of chemical pollution. If the Soviats had failed to permit their irradiated reactor fuel elements to cool the normal 6-month period (and, in the rush to produce plutonium at that time, one might expect they would not), then the off gases would also contain appreciable amounts of radioactive iodine. iodine-131.

The destructive po:yer of acid rain alone, not compounded by radioactive iodine contamination, is appalling. In the Adirondack Mountains of New York the acid rain includes a mixture of sulfuric and nitric acids from the sulfur dioxide and nitrogen oxides pouring from the smokestacks of power plants, smelters, factories, and vehicle exhausts. Over 200 lakes are dead; their aquatic life gone or dwinling. And in Scandinavia acid rain has destroyed 15,000 lakes in recent years. Inevitably, the death of a lake affects other wildife as well; fish-eating ducks, loons, otter, mink, and even birds begin to leave, because their food and shelter have been destroyed. On the ground, acid rain leaches essential nutrients from the soil--calcium, magnesium, potassium, and sodium. It prevents some seeds from germinating; it scars 
leaves and erodes their protective coating.* Professor Tumerman's 1960 eyewitness description of the Kyshtym environs, "the land was 'dead," would certainly be appropriate to a countryside that had been subjected to acid rain conditions continuously for almost 10 years.

We have now identified two sources of contamination for the Techa River Valley--waterborne from the open cycle cooling of the reactors and airborne from the chemical processing plant. But, there may even be a third.

\section{WASTE DISPOSAL}

The processing of irradiated fuel elements to recover the plutonium is accompanied by the production of radioactive waste. At Hanford, high-level radioactive liquid and solid wastes are stored in underground carbon steel tanks with capacities ranging from 50,000 to $1,000,000$ gallons.

Between 1944 and 1964,149 single-shell tanks were constructed at Hanford. Today, less than 30 single-shell tanks are actively used to store liquids, and these are being removed from service. They are being replaced with 1,000,000-gallon-capacity double-shell tanks--concrete-reinforced vessels with two double carbon scieel liners--a tank within a tank.

But, what was the situation at kyshtym in the late 1940s1950s? Given tha pressure stalin exerted on the scientists to obtain a nuclear bomb, and given the soviet general disregard for its citizenry, they might have resorted to ground disposal for radioactive liquid waste.

We postulate that that is what the soviets initially did at Kyshtym. A dry lake bed exists $5-6 \mathrm{~km}$ southeast of the complex, and we postulate that radioactive liquid waste was disposed of in this region. The natural drainage of this area is east toward the Techa River, and it may have been anticipated that the heavy metals would settle out onto the bottom of the lake while the

*Robert Collins, "Acid Rain: Scourge from the Skies," Reader's Digest, January 1981 . 
liquids would eventually be disposed of by ground absorption, evaporation, or eventual entry into the Techa River downstream of the complex.

This method of waste storage would then provide a possible third source of contamination for the river valley.

\section{REMEDIAL MEASURES}

History recorded the success of the soviet plutonium production facility with the detonation of the first soviet nuclear weapon in late 1949. How soon after that success the Soviets became cognizant of the havoc they were wreaking in the Techa River Valley is unknown. But, information released in 1972 under the US Freedom of Information Act indicates that:

$$
\begin{aligned}
& \text { ". . . as early as } 1954 \text {. . . the water of the } \\
& \text { Techa River, running from Lake Kyzyltash and } \\
& \text { Lake Ulagach and emptying into the Iset River } \\
& \text { at Dalmatovo, had become highly radioactive." }
\end{aligned}
$$

A. Evacuation of populace

The Techa River Valley was populated by the Bashkir, a poverty stricken people of Turkic ancestry whose chief occupation was farming. Livirg conditions for them were rather primitive. Dwellings were predominantly of wood, wattle, and adobe construction. They would have had to rely on the Techa River not only for their fresh water supply but also for a large part of the protein supply in their diet--fish, waterfowl.

We believe they were subjected to waterborne radioactive contamination from the production reactors upstream, perhaps as early as the late 1940s. This not only affected the water they drank and the crops they farmed, but the fish and waterfowl they consumed as well. Available information indicates that radioactive water flowing out of the complex caused serious health problems for humans and livestock. In 1953 or 1954, according to rumor, radiation sickness appeared among the people and cattle, and possibly among the people and cattle of other settlements further downstream. 
Additionally, from at least 1951 on, the Bashkir were subjected to aerosol contamination from the chemical separation facility at the plutonium production complex--chemical in the form of acid rain and perhaps radioactive in the form of iodine-131. This would have compounded the hardship of Bashkir life in the Techa River valley. Further, information states that:

". . poisonous gases from a smokestack killed vegetation over a distance of many kilometers."

The only logical course of action was evacuation of the populace. This procedure, however, was probably not as monumental as it might at first appear. There were no urban areas along the Techa--it was a sparsely populated, rural, farming region. And, the evacuation of entire villages is not without precedent even in the US. Two towns originally located on the Hanford Reservation, White Bluffs Townsite and Hanford Townsite, were evacuated, almost overnight, for security and safety reasons prior to the construction of the plutonium production reactors there. In fact, today the roofless high school building and the bank from Hanford Townsite stand as mute testaments to that relocation, but not to any devastating accident. So, too, the evacuation of the Bashkir would have left behind abandoned dwellings.

Both Medvedev and Tumerman described burned out dwellings with only chimneys left standing. However, how could the authorities explain to illiterate farmers that the clear water flowing past their homes was hazardous, or that they must not hurt or $f$ ish along that river. The only logical course of action was relocation followed by destruction, most probably by fire, of the farmers' homesteads. Thus, we can account for the "massive" evacuation and burned out dwellings without even opening the possibility of a nuclear disaster in the region.

Apparently the Soviets profited from their experiences at Kyshtym. A. I. Burnazyan, * Deputy Minister of Health, USSR, whose

*A. I. Burnazyan, Atomnaya Energiya 39, No. 3, 167-172, September 1975 . 
administration was responsible for the health of workers in institutions belonging to the Ministry of Medium Machine Building, such as Chelyabinsk-40, published in 1975 on the necessity for establishing a health protection zone around nuclear power stations in. the USSR.

"Selection of a site for the location of a nuclear power station on a health basis is of exceptional importance in the creation of safe operating conditions. A nuclear power station, as far as possible, should be located in an area of low population with good natural ventilation of the area toward the leeward side with respect to populated areas. The selection of a site in a basin or in an area with slight air movement and with a large number of calms is not recommended. The hydrogeologic conditions of the area should eliminate the possibility of radioactive materials entering ground water. The highest level of standing ground water must be not less than $1.5 \mathrm{~m}$ below the outline of a tracer field from the proposed structures produced by radioactive methods.

The location of a nuclear power station must admit the possibility of arranging a healthprotection zone around the station, the size of which is established separately in each specific case in conjunction with units of the state Health Protection Group depending on local. climatic, meteorological, and topographic conditions; the type, construction, and power of the reactor; the calculated amount of radioactive discharge into the atmosphere and its surface concentration, etc. In the healthprotection zone, one forbids continuous residence by individuals, the location of health establishments and food-processing plants; but one allows the construction of subsidiary and auxiliary structures and buildings for the nuclear power station, the growth of agricultural products, pasturage of cattle, etc. subject to compulsory radiometric monitoring of this area and of the products produced in it."

B. Reactor Cooling Cycle Modifications

It is a logical follow-on that shortly after the Bashkir evacuation, the soviets would have instituted remedial measures to 
modify the cooling water flow pattern and thereby alleviate the waterborne contamination of the Techa River Valley.

Information indicates that the original designers probably thought that the radioactive elements would settle out while the cooling water effluent stood in the artificial lake, and would thereby leave only pure water to flow downstream. When this did not work, they probably dug additional holding ponds or lakes in the Industrial zone to permit longer periods of settling. When this also failed, they simply banned the use of the water. Extensive civil engineering projects were implemented sometime prior to the publication of a 1973 map of the Kyshtym area (Fig. 3). Lake Kyzyltash has effectively been isolated by the construction of three dams and a series of navigable canals that bypass the lake. Two new lakes (holding ponds) exist in the Techa River Valley, and villages that appeared on the earlier map (Fig. 2) are now covered by the holding ponds. The surface area of each of these ponds is larger than that of Lake Kyzyltash itself. The reactor coolant water in Lake Kyzyltash can be transferred to and held up in the first pond because a dike separates the first and second ponds. A second series of dikes controls the flow from the second pond into the Techa River.

As seen in Fig. 3, Lake Kyzyltash is no longer fed by Lake Irtyash because the stream that connected the two lakes has been dammed. The water from Lake Irtyash is diverted around Lake Kyzyltash through a series of navigable canals north of the area. Uncontaminated water from Lake Irtyash is diverted through Lake Berdanish and around the holding ponds. Diversion canals also follow the southern perimeter of the ponds.

clearly, the Soviets recognized the problem and instituted rather extensive remedial measures to remedy it. They may also have altered the cooling cycle of the reactors and gone from open to closed cycle cooling. In 1975, A. I. Burnazyan* also published on the importance of closed-loop cooling cycles.

ॠIbid. 


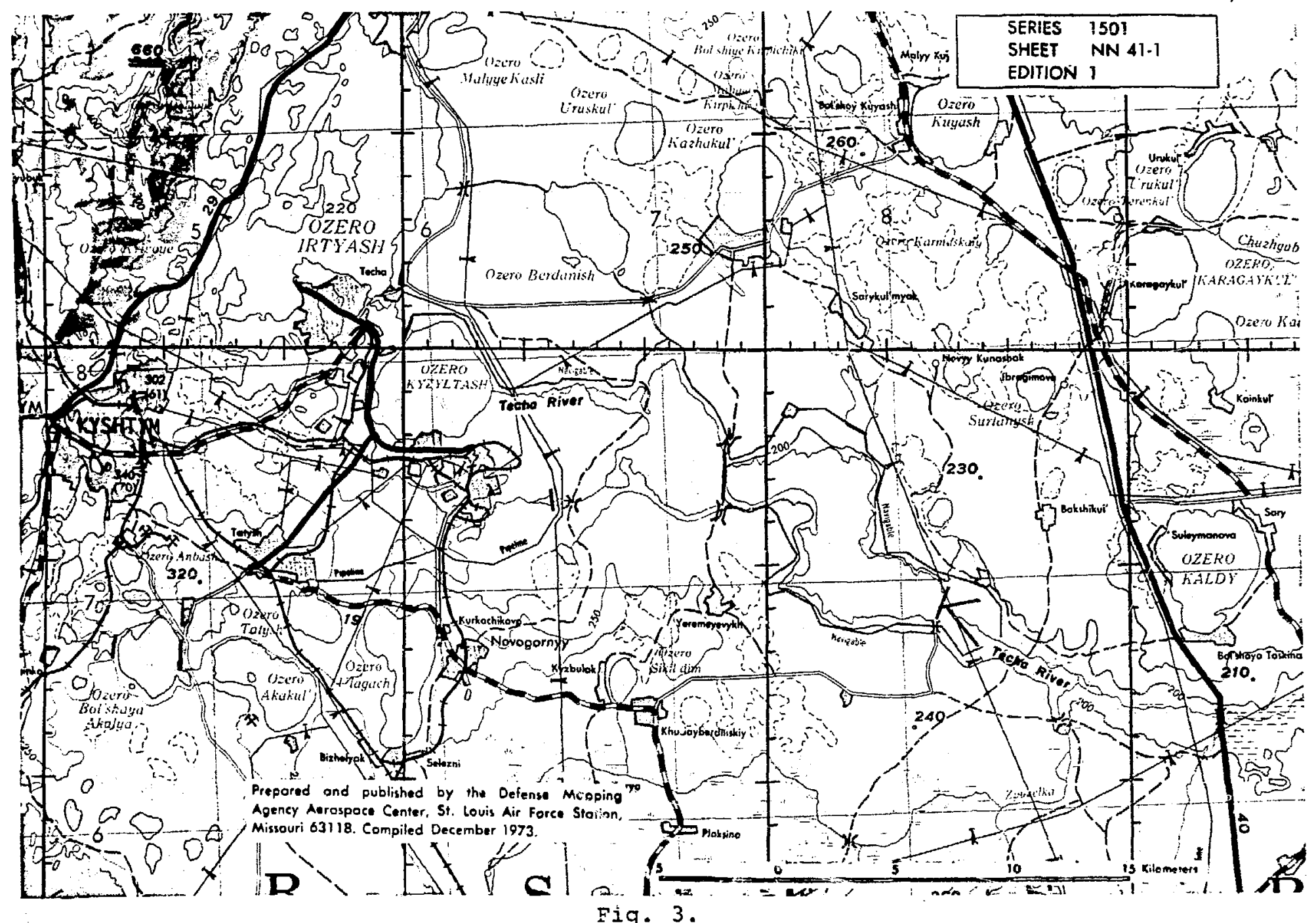

Kyshtym area (post-compiex). 
"A possible means for the entrance of radioactive materials into open water supplies, besides drain waters, is the technical water supply system intended for cooling turbine condensers and other equipment. However, the scheme for technical water supply was developed with a design that completely eliminated the possibility of radioactive materials entering the cooling water. At a nuclear power station with VVER reactors, this is achieved by means of two hermetically isolated closed loops. The technical water supply system forms a third loop, the radioactive contamination of which is impossible under the conditions specified. The possibility of radioactive contamination of process water is also prevented by an increase in the pressure of process water to a value higher than the pressure in the turbine condensers."

\section{Off Gases}

No doubt better methods of filtering and trapping the off gases frcm the enrichment plant were also instituted. And, perhaps, the reactor fuel elements were permitted to cool for longer time periods once the political pressure to produce the first atomic bomb had been lifted. This would have lessened the concentration of radioactive iodine in the off gas.

\section{Waste Disposal}

Finally, if the Soviets had used open-pond waste storage as postulated, they had to eventually realize that it had only been a temporary solution at best. When they constructed a waste treatment facility and where they constructed their storage tank farm have not been determined.

What then happened to the liquid waste pond? Open literature articles suggest the Soviets experimented with a novel approach to the disposal of radioactive liquid wastes as early as 1952 .

N. V. Timofeyev-Resovskiy has been identified by Medvedev and others as a scientist connected with chelyabinsk-40 during the 1950s. A review of publications by N. V. Timofeyev-Resovskiy showed that he not only conducted radioecological research during that time period but even coined a new word "biogeocenology." Biogeocenology stresses the interdependence of radioisotope 
migration with the geology, geochemistry, and biomass of the environment. Specifically, Timofeyev-Resovskiy's research centered on attempts to deactivate radioactive water (concentrations of up to several tenths of a microcurie per liter) in two ponds using fresh water organisms (plankton, periphyton) and soil/sand filters. He described the radioactive water as a mixture of "uranium debris" containing strontium, yttrium, zirconium, niobium, ruthenium, cesium, and cerium, as well as phosphorus, sulfur, zinc, iron, and cobalt. The use of the term "uranium debris" could suggest that Timofeyev-Resovskiy was experimenting with waste generated either in the separation of plutonium from irradiated fuel elements or in a secondary separation of uranium from fission products.

The fact that the Soviets were actively engaged in research on ponds (open-pond liquid-waste storage) lends credence to our suggestion that the Soviets may have initially used open-pond waste storage at Kyshtym.

While such research was in progress, what happened to the liquid waste pond at Kyshtym? It may have been pumped out for reprocessing or tank storage, or it may simply have been left undisturbed to either wait for Timofeyev-Resovskiy's research to reach fruition or to let the liquid evaporate or enter the ground water over time. The Soviets may have planned to simply bulldoze, cover over, the waste pond after the heavy-metal contaminants had precipitated out on the bottom of the lake.

The soil cover in the Kyshtym area ranges from chernozem ("black earth") and podzolic soil in the forested areas to clays in the flood plains. What then may have happened as the liquid in the waste pond began to evaporate? The more highly soluble contaminants would probably have begun to migrate with the liquid to the deepest part of the basin. Eventually, the most soluble contaminants would precipitate out in this region and adhere to the clay particles. Cesium and strontium, fission products found in high-level radioactive wastes, both form highly soluble salts. The concentration of cesium and strontium salts would be greatest at the deepest part of the storage pond. 
At this point the soviets could have been more vulnerable to causing widespread aerosol contamination than at any other point in their previous history of sloppy practices at kyshtym.

There are two possible mechanisms for dispersal of these highly contaminated clay particles--one natural, both uncontrollable.

A study of local weather trends in the Kyshtym area has led to some interesting observations--one of which indicates that during late February and early March there are sudden gusts of wind (up to $100 \mathrm{~km}$ per hour) that last about 2 hours, subside, and then start up again.

If the time lag between the drainage of the pond and the coverage of the clay bottom with soil/sand occurred during the erratic spring windy season, aerosol contamination could be deposited in widespread, noncontiguous regions around kyshtym by a natural dispersal mechanism, wind.

An explosive dispersal mechanism for the contaminated clay particles may also have been possible, predicated on the soviet receipt of an unintentional piece of information from Hanford. This possibility is investigated in the following paragraphs.

Although the effectiveness of the coprecipitation process for separation of plutonium had been successfully exploited to produce erough plutonium for an atomic weapon, Hanford continued to conduct research and development in alternative separation schemes. one such scheme, the Redox method, utilized ammonium nitrate and hexone. Hanford never used ammonium nitrate but, at one time, large quantities of ammonium nitrate had been purchased, marked as such, and stored outside in large piles on the Hanford Reservation. If the soviets acquired this piece of information, they may have used a Redox-type process involving both ammonium nitrate and hexone. The radioactive waste pond would then also have contained both ammonium nitrate and hexone.

Using the earlier scenario of open-pond waste storage, the waste pond storage problem would have been compounded by the presence of ammonium nitrate and hexone, a flammable solvent. As the liquid evaporated from the pond, the ammonium nitrate (a highly 
soluble compound) would also migrate to the deepest region of the basin, precipitate out, and adhere to the clay particles. Molecules of the flammable solvent, hexone, would be trapped along with the fission product salts that had migrated to the deeper region of the basin along with the liquids. The potential for a Texas city-like explosion was then present: ammonium nitrate and a fuel (hexone) in a confined area (the compacting layers of clay). If such an explasion did accur, aerosol contamination could be spread over a vast area. It would be an explosion involving nuclear waste as Medvedev states, but it would be a chemical explosion, not a nuclear explosion.

The dispersal of aerosol contamination from an abandoned, dried-up waste pond whether by natural means (wind) or chemical means (ammonium nitrate explosion) is consistent with the following information concerning the defoliation of trees due to a fallout of red dust and with a number of reports on remedial measures instituted by the soviets in the 1960 s and 1970s.

A former resident of the Chelyabinsk oblast at the time of the so-called Kyshtym disaster, has related the following story: ". . while I was visiting my friend, who was in a hospital for a heart condition, I mentioned to her that something unusual was occurring in Yemanzhelinskaya. I told her that all the leaves on the trees in and around Yemanzhelinskaya and surrounding areas were completely covered with a fine layer of red dust. Very quickly all the leaves on the poplar trees became extremely sininy brown, curled up and fell off. Leafy green vegetables were covered with this same type of dust and curled up and died.

I also told her at that time that there were announcements over the radio and also through the newspaper media acclising the Us of transmitting poison through the air which was carried by the rain falling all over the Chelyabinsk oblast causing people to be burned and destroying trees and vegetation. The people were advised not to wash their clothes or hair in the rain water because they would be burned. The newspaper which I received in Yemanzhelinskaya was called the 'Trud.' Water for the 
homes was supplied by pipe lines which came from Chelyabinsk.

My friend had been in this new hospital for approximately three months. . . I do not remember if this hospital had a name but it was new, four stories high, .. . and located on Zeleniv Magazin Ulitsa (Green Magazine Street) which is in the southern section of Chelyabinsk.

My friend told me that in talking with other patients in the hospital, including the employees, she was advised that sometime in April 1960 a terrific explosion (vzriv) occurred somewhere in the Chelyabinsk Oblast. Unfortunately, no one knew where this blast occurred but there was talk that there was a 'secret zone' approximately 50 to 60 kilometers from Chelyabinsk and where this explosion occurred. Also that this secret zone was supposed to be in dense woodlands and cleverly camouflaged. Unfortunately I have no idea as to what direction this zone is located from Chelyabinsk.

Both my friend and I saw some of the people in this hospital who we were told came from the area where the explosion had occurred. Some of them were bandaged and some were not. We could see the skin on their face, hands and other exposed parts of the body to be sloughing off. These victims of the blast were brought into this hospital during the night. It was a horrible sight. From my friend's room, which was on the fourth floor of the hospital, we were able to see these people walking around on the hospital grounds...

The victims of the blast were placed in one wing of the hospital. None of them were permitted to leave this wing or to talk with other patients. Other patients were not permitted to talk with these victims or even visit with them. Those who promenaded around the hospital grounds were all by themselves and the area was sectioned off so no one could get near them.

Both my friend and I had no idea what the cause of the explosion was nor did we know of any destruction or damage to any facilities or town where the explosion may have occurred. I have no idea where this explosion occurred, nor what time of day or date, except that my friend told 
me that this blast occurred sometime in April 1960.

The prohibited zone where the explosion occurred is 'only' open to die hard Communist Party members and workers who also lived there."

The above account could be explained by natural dispersal of the contaminated red clay particles by the spring winds. Or, if we consider the blast victims, a chemical explosion could have provided the dispersal mechanism. The rapid blackening of leaves and attendant defoliation suggest the presence of an excessive amount of a plant fertilizer. Ammorium nitrate and ammonium sulfate are both commercial, chemical fertilizers. The rapid defoliation could have been due to these compounds adhering to red clay particles on the bottom of the waste pond followed by an aerosol dispersa! via some mechanism. The rapidity of the defoliation suggests a fertilizer effect rather than a reaction to radioactivity because the latter response would not have been as fast acting.

At this point the soviets had to realize that covering the contaminated dry lake bed was essertial to proventing further aerosol dispersal of the contaminated particles. Remedial measures were probably instituted sometime in the 1960s. Information indicates that they used volunteer prisoners to dump truckloads of sand on top of the contaminated soil. The surface of the contaminated area was covered with more than 1 in of soil. When the dump trucks used for this purpose became too contaminated, they were simply abandoned inside the contaminated area ard eventually covered with soil. The truck drivers were referred to as "death people" or "death squad." They were prisoners with 10- to 15-year sentences whose time in prison would be reduced through their volunteering for this duty. They lived in special barracks, and it was thought they would probably die there.

other information has revealed that the scil in the contaminated area (the dry lake bed area) was reddish in color and had the consistency of clay. When the soil was wet it stuck to one's 
shoes and was difficult to remove. This observation lends credence to the suggested source of the red dust defoliant as the contaminated dry lake bed.

The last measure adopted by the Soviets cannot be called remedial but could be classified utilitarian. The Soviets chose to utilize the contaminated dry lake area as an active radiological training range for their Chemical-Biological-Radiological troops.

Civil defense exercises in this area have been described as follows:
". . tank reconnaissance platoons from
Taurage were sent for a one-month simulated radiological reconnaissance exercise to the Chelyabinsk All-Union Radiological Maneuver and Exercise Range... in Chelyabinsk. . . the reconnaissance personnel were required to drive in a radioactively contaminated area for about 20 minutes, sampling the radiation levels in the area."

Additional information concerning radiological training exercises near Chelyabinsk indicates that:

"When the test range was initially explained to the $C D$ troops and their captain, they were told that the sita was radioactively contaminated and that the cause of this contamination was a reactor explosion that occurred in 1956... . the reactor was named in honor of the famous physics Professor (Igor Vasilyevich) Kurchatov because he had been asked to 'organize' the nuclear reactor project in that area during the early history of the nuclear program."

Here, again, the connection between Kurchatov, the first plutonium production facility, and the kyshtym complex is evidenc. In addition, the complex is identified as the causative agent for the contaminated area.

It has been reported that the troops were told that the area of the radiological range was approximately $40 \mathrm{~km}^{2}$. The report was not positive as to the geometric shape of the area but implied that it was circular. If this is so, the radius would be less than $4 \mathrm{~km}$. The contaminated area has been referred to by several names: Active Radiological Range, Active Radiological Test Site, 
and Chelyabinsk Active Radiological Range. There was reportedly an "imitation" radiological training site in the Kaliningrad $\left(54^{\circ} 43^{\circ} \mathrm{N}, 20^{\circ} 30^{\prime} \mathrm{E}\right)$ area, but the only active radiological training area was the one in the Chelyabinsk region. Further descriptions of the area state that:

"The barbed wire perimeter fence for the contaminated area had warning signs saying

'Restricted Zone--No Entry.' There was no gate at the entrance, just an open section in the fence. The fence, which was interrupted by open sections--often consisting of old collapsed fencing--consisted of barbed wire and wooden posts or boards, but no solidly boarded portions. Troops were told that there was no radioactivity outside the first perimeter fence, but they were still forbidden to use snow for washing (under normal circumstance, it would have been common practice at the barracks for the troops to use snow to wash their hair, for instance, since the local water was very hard).

Approximately one kilometer beyond this fence was another barbed wire fence with signs saying 'Forbidden Zone' and 'Radiation--Danger to Life.' About another kilometer beyond this second fence there was said to be a third fence, enclosing an even more highly radioactive zone, with stricter signs saying 'Danger to Life--Radioactive.' The second fence could be seen from the entrance, although the signs could not be read at that distance. The third fence was reported to exist and was assumed to be about as far beyond the second fence. At that entrance, the fenced area was hilly and seemed to be circular, since the fence curved away from the entrance."

The "hills" in the most highly contaminated area were probably created by the dumping of truckloads of sand/dirt by the death squads. And, concentric areas of contamination with the central region being most highly contaminated are suggestive of the evaporative waste pond scenario wherein the more highly soluble fission products would precipitate out in the deepest region of the pond. 


\section{CONCLUSIONS/ACCIDENTS}

What then did happen at Kyshtym? A disastrous nuclear accident that killed hundreds, injured thousands, and contaminated thousands of square miles of land? Or, a series of relatively minor incidents, embellished by rumor, and severely compounded by a history of sloppy practices associated with the complex? The latter seems more highly probable.

No doubt Kyshtym had its share of small reactor fires when reactor fuel elements, for example, would get hung up during refueling operations. No doubt the chemical separation plant was vulnerable to chemical accidents and explosions just as any chemical plant is. And, no doubt the radioactive waste storage practices at the kyshtym Complex are subject to suspicion. In fact, we can even account for "volcano-like" explosions at the complex. It has been reported that the excavation for one of the Kyshtym reactors may have been in excess of $50 \mathrm{~m}$ square by $50 \mathrm{~m}$ deep. Excavating to that depth would have required the use of hundreds of tons of buried explosives, and the detonation of these explosives could easily have been described by an external observer as "volcano-like," especially if the detonation were at night.

It has even been suggested that "the accident" in 1958 may really have been a soviet nuclear weapons test that went awry . The New York Times of April 14, 1958, carried the following article:

\section{"Soviet Catastrophe Reported}

Copenhagen, Denmark, April 13 uP -- Berlingske Tidende, Denmark's biggest newspaper, said today the recent soviet nuclear tests had to be broken off because of a 'catastrophic accident.'

The newspaper, quoting information reaching Copenhagen through diplomatic channels from Moscow, did not define the nature of the reported accident, but said it caused radioactive fallout over the Soviet and many neighboring states to increase to the danger point.

It is said this was probably the real reason the Soviet Government stopped testing unilaterally last month, adding that the Russians could not 
risk continuing tests of arms with serious defects،"

"The accident" in 1958, referred to by so many, may not even have been associated with the plutonium production facility at Kyshtym. It may have been a weapons test gone awry as the above article indicates. On the other hand, "the accident" could have involved Soviet production facilities at Kyshtym or elsewhere. Further corroborative accounts are being researched and both possibilities are being studied.

But, what did happen at Kyshtym? A disastrous nuclear detonation in buried nuclear reactor wastes? Hardly--the Soviets managed to contaminate the Techa River Valley without any help from such a catastrophe. They began in the late 1940 s to divert waterborne radioactive contamination down the river in the form of contaminated reactor cooling water. They compounded this error with aerosol contamination in the form of chemical and radioactive pollutants from their chemical separation plant. And finally, their nuclear waste disposal practices may have provided a third mechanism for the spread of radioactive contaminants through the valley.

The Soviets successfully, albeit rather unsensationally, created a contaminated area near Kyshtym through carelessness and blatant disregard for their people or their surroundings. The Kyshtym disaster is just that--a record of the disastrous, long lasting effects man can wreak on his environment if he fails to take adequate steps to protect it. 